\title{
Evaluation of Toraja (Indonesia) local aromatic rice mutant developed using heavy-ion beam irradiation
}

\author{
ANDI MULIARNI OKASA ${ }^{1, \bullet}$, RINALDI SJAHRIL ${ }^{2, \bullet \bullet}$, MUHAMMAD RIADI $^{3}$, META MAHENDRADATTA ${ }^{4}$, \\ TADASHI SATO ${ }^{5,6}$, KINYA TORIYAMA ${ }^{5}$, KOTARO ISHII ${ }^{6}$, YORIKO HAYASHI ${ }^{6}$, TOMOKO ABE ${ }^{6}$ \\ ${ }^{1}$ Graduate School of Agricultural Science, Universitas Hasanuddin. Jl. Perintis Kemerdekaan Km. 10, Makassar 90245, South Sulawesi, Indonesia. \\ "email: andimuliarniokasa10@gmail.com \\ ${ }^{2}$ Laboratory of Plant Bioscience and Reproduction Biotechnology, Department of Agronomy, Faculty of Agriculture, Universitas Hasanuddin. Jl. Perintis \\ Kemerdekaan Km. 10, Makassar 90245, South Sulawesi, Indonesia. Tel./fax.: +62-411-587064, "^email: rinaldi.sjahril@gmail.com \\ ${ }^{3}$ Laboratory of Plant Breeding and Seed Science, Department of Agronomy, Faculty of Agriculture, Universitas Hasanuddin. Jl. Perintis Kemerdekaan \\ Km. 10, Makassar 90245, South Sulawesi, Indonesia \\ ${ }^{4}$ Laboratory of Chemical Analysis and Food Quality Control, Department of Agricultural Product Technology, Faculty of Agriculture, Universitas \\ Hasanuddin. J1. Perintis Kemerdekaan Km. 10, Makassar 90245, South Sulawesi, Indonesia \\ ${ }^{5}$ Laboratory of Environmental Biotechnology, Graduate School of Agricultural Science, Tohoku University. Sendai, Miyagi 980-85727, Japan \\ ${ }^{6}$ RIKEN Nishina Center for Accelerator-Based Science. 2-1 Hirosawa, Wako, Saitama 351-0198, Japan
}

Manuscript received: 30 April 2021. Revision accepted: 27 July 2021.

\begin{abstract}
Okasa AM, Sjahril R, Riadi M, Mahendradatta M, Sato T, Toriyama K, Ishii K, Hayashi Y, Abe T. 2021. Evaluation of Toraja (Indonesia) local aromatic rice mutant developed using heavy-ion beam irradiation. Biodiversitas 22: 3474-3481. The aromatic local Toraja rice "Pare Bau" has a good grain quality and aroma. However, it has some disadvantages, including a late heading and low yield for a modern farming system. This study aims to evaluate and select early heading as well as high yield mutant lines induced by heavyion beam irradiation. Furthermore, dry seeds of Pare Bau were irradiated with Argon-ion $(300 \mathrm{keV} / \mu \mathrm{m})$ and Carbon-ion $(30 \mathrm{keV} / \mu \mathrm{m})$ at RI-beam factory, RIKEN Nishina Center, Japan. The germination percentages of the $\mathrm{M}_{1}$ seeds were $49 \%$ for Pare Bau irradiated with Argon-ion (PB-A), 53\% for Pare Bau irradiated with Carbon-ion (PB-C), and 70\% for the Control. The 13 PB-A and 13 PB-C M 1 plants were selected, and the seeds were sampled in the paddy field of Hasanuddin University $(20 \mathrm{~m}$ asl.), Makassar. During the following planting season, the $\mathrm{M}_{2}$ generation plant was examined in Enrekang District (650 m asl.), South Sulawesi, Indonesia. Based on the early heading and a larger number of panicles, the $18 \mathrm{~PB}-\mathrm{A}$ and one PB-C $\mathrm{M}_{3}$ line were selected from a total of $404 \mathrm{M}_{2}$ survival plants. The selected lines and control were grouped into seven clusters based on the quantitative phenotypic traits, indicating the existence of genetic variability. The plant yield was significantly correlated with plant height, the number of tillers, the number of panicles, as well as grain weight per panicle, which showed that these traits are good criteria for selection.
\end{abstract}

Keywords: Early heading, heavy-ion beam, high yield, mutant, Toraja cultivar

Abbreviations: LET: Linear energy transfer; PB-A: Pare Bau irradiated with Argon-ion; PB-C: Pare Bau irradiated with Carbon-ion

\section{INTRODUCTION}

Tana Toraja is a highland region in South Sulawesi, at an altitude of $700 \mathrm{~m}$ to $1425 \mathrm{~m}$ asl., with a rich biodiversity of local rice that has yet to be exploited. Maulana et al. (2014) examined 18 local rice varieties from Tana Toraja that showed high diversity based on Random Amplified Polymorphic DNA (RAPD) markers. One of the local varieties known as the local aromatic rice is "Pare Bau" which has unique characteristics such as pleasant aroma, better taste, and higher grain quality and has additional socio-economic aspects. However, it also has several disadvantages, including the late heading, high plant posture, and low yield.

The heading date and yield are important traits that determine the productivity of many crops. Furthermore, the heading date is a trait that is closely associated with the regional adaptability of rice varieties and is controlled by internal signals and the environment (Kobayashi and Weigel 2007). The yield was determined by sink (the number of panicles, number of grains, and grain weight) and source (Huang et al. 2013; Khush 2013). It is controlled by external environmental conditions and is governed by genes (Zhang et al. 2017). Furthermore, the primary strategy for increasing production is an increase in rice yield. The heading date has a significant impact on the agronomic traits related to the yield (Jung and Muller, 2009). Several researchers studied the relationships between heading date and yield in rice (Augustina et al. 2013; Ye et al. 2018; $\mathrm{Hu}$ et al. 2019). However, manipulation of the early heading date and high yield in rice is an important objective in breeding programs.

Previously, conventional breeding was used to develop new varieties, but breeders were unsatisfied with the results. One of the most effective ways to improve the traits of plants is through mutation breeding, which has been actively practiced for over half a century, with the joint FAO/IAEA Division based in Vienna helping developing countries to adopt advances in the technology quickly (Jain 2005). Mutation breeding can be advantageous in the 
production of varieties with the desired trait within a defined germplasm diversity. Furthermore, several achievements have been obtained through mutation breeding regarding improving rice grain quality (Luz et al. 2020).

Plant breeding using ion beam irradiation is a unique technology. Heavy-ion beams are often used as a novel physical mutagen in plant breeding (Abe et al. 2012). Due to their high linear energy transfer (LET), the mutagenic efficiency of heavy-ion beams was significantly higher than that of all other physical mutagens such as gamma rays (Kazama et al. 2011). The ion beam irradiates the samples via an automatic irradiation system, expected to produce double-stranded DNA fractions (Abe et al. 2012). Several studies have been carried out on the mutagenic effect of ion beam irradiation on rice (Ishikawa et al. 2012, Zheng et al. 2020), such as from immature embryos (Fekih 2013), callus obtained from seeds (Mostafa et al. 2015), and cell suspension cultures (Chen et al. 2013). However, seeds are easier to handle and do not require any specialized structure, making them the most commonly used material (Hayashi et al. 2018).

Only a few studies have been conducted using heavyion beam irradiation in local aromatic rice, especially in Indonesia. Furthermore, screening and creating a new mutant variety with improved traits is also a primary goal for future studies. Therefore, this study aims to evaluate and select early heading as well as high yield mutant lines from local Toraja aromatic rice "Pare Bau" induced by heavy-ion beam irradiation.

\section{MATERIALS AND METHODS}

\section{Plant materials and irradiation treatment}

In the present study, $\mathrm{M}_{0}$ seeds of local aromatic rice varieties (Oryza sativa L. var 'Pare Bau') were obtained from Toraja Agriculture Office, South Sulawesi, Indonesia. Dry rice seeds were placed in a plastic box in a single layer due to the limited range of the Argon-ion beam. Furthermore, a sponge was used as a lower surface in the plastic rectangular box $(75 \times 50 \times 18 \mathrm{~mm})$. The seeds in a single layer were pressed between the sponge and the cover plastic of the box. The seeds were then irradiated with Argon-ion at a dose of $10 \mathrm{~Gy}$ and Carbon-ion at a dose of 150 Gy at the RI-beam factory, RIKEN Nishina Center, Japan. The average LET of each ion was calculated to be $300 \mathrm{keV} / \mu \mathrm{m}$ for Argon-ion and $30 \mathrm{keV} / \mu \mathrm{m}$ for Carbon-ion.

\section{Experimental site and crop cultivation}

The experiment was carried out in the paddy field of Hasanuddin University, Makassar, Indonesia (S: 5²753.50" E: $119^{\circ} 28^{\prime} 57.97^{\prime \prime} ; 20 \mathrm{~m}$ asl.). While the $\mathrm{M}_{2}$ generation was carried out in the paddy field of mountainous Enrekang District, South Sulawesi, Indonesia (S: 3º19'47.44" E: 11950'1.57"; $650 \mathrm{~m}$ asl.) neighboring to Tana Toraja District, South Sulawesi, Indonesia.

\section{Evaluation of $M_{1}$ generation}

To measure the germination percentage, 1000 seeds from each treatment were sown in small plastic seedling pots and grown in a screen house. The germination percentage was calculated based on the following formula:
Germination percentage $(\%)=\frac{\text { No.of seeds germinated }}{\text { No. of seeds sown }} \times 100$

All mutant and 100 control seedlings were transplanted in the paddy field. Plant survival was recorded at the maturity stage. $\mathrm{M}_{2}$ seeds were harvested from individual $\mathrm{M}_{1}$ plants on a panicle. The $13 \mathrm{~PB}-\mathrm{A}$ and $13 \mathrm{~PB}-\mathrm{C} \mathrm{M}_{1}$ plants were selected, which showed 50 larger numbers of grain per panicle, and then sampled.

\section{Evaluation of $\mathrm{M}_{2}$ generation}

During the following planting season, fifty seedlings per each 13 PB-A, 13 PB-C $\mathrm{M}_{2}$ lines, and control were transplanted using a single plant per hill in paddy field. The distance between hills was $30 \mathrm{~cm}$ x $30 \mathrm{~cm}$. The number of transplanted $\mathrm{M}_{2}$ mutant seedlings was 650 . The panicles on the plants were cut and placed in individual paper bags, where they were dried for several days to produce $\mathrm{M}_{3}$ seeds.

\section{Data collection and statistical analysis}

The data collection was carried out on the plant height $(\mathrm{cm})$, heading date (day), the number of tillers, the number of panicles, grain weight per panicle $(\mathrm{g})$, the number of fertile grains, the number of sterile grains, 100-grain weight (g), and plant yield (g). The early heading and a larger number of panicles were used as selection criteria. To avoid the scaling problem, the selected traits were normalized and mapped in two dimensions. The mutant frequency was calculated using the following formula:

$$
\text { Mutant frequency }(\%)=\frac{\text { No.of mutant plants }}{\text { No. of population }} \times 100
$$

A dissimilarity matrix was generated based on the Squared-Euclidean distance across nine quantitative phenotypic traits between the lines and control. This matrix was used with a hierarchical clustering technique of the Wards Minimum variance method, and results were presented graphically in the dendrograms (Ward 1963). Furthermore, the phenotypic correlation was analyzed to see the correlation among traits. A dissimilarity matrix, hierarchical clustering, and correlation analysis were performed using SPSS software.

\section{RESULTS AND DISCUSSION}

\section{Generation of the mutant population}

In the current study, the germination percentage and the number of survival plants among 2000 mutagenized seeds and control during $\mathrm{M}_{1}$ generation were observed. The germination percentages of $\mathrm{M}_{1}$ seeds were $49 \%$ for PB-A, $53 \%$ for $\mathrm{PB}-\mathrm{C}$, and $70 \%$ for control (Figure 1). The germination percentages above the control decreased for PB-A by $21 \%$ and PB-C by $17 \%$. This may be due to the harmful effects of the ion beam on the $\mathrm{M}_{0}$ seeds, which weakened the embryo. The seeds can absorb the mutagen, which then penetrates the meristematic zone and affects the germ cell, leading to a reduction in germination (Ke et al. 2019). Similarly, the reduction in germs can be attributed 
to damage to the cell components (Kumar et al. 2013). Physiological and biological processes are slowed or inhibited due to changes in enzyme activity (Talebi et al. 2012). In addition, due to field conditions, which include heavy rain for the first few days after planting, some seedlings even grew until the early vegetative stage but died before the pod set. The normal grown-up seedlings were 94 PB-A, 79 PB-C, and 57 for control. In the $\mathrm{M}_{1}$ generation, the condition was heterozygous, in such a way that most mutations were recessive and are not expressed in the first generation. The plants with seeds larger than 50 were selected and ensuring the survival of the $M_{1}$ generation plant is beneficial. The possibility of phenotypic mutation was extremely low during $\mathrm{M}_{1}$ generation, and only dominant mutations can be detected genetically (Roychowdhury and Tah 2013). The use of a heavy-ion beam has been shown to reduce seed germination.

\section{Evaluation of $\mathrm{M}_{2}$ generation}

Survival plants in the $\mathrm{M}_{2}$ generation were $196 \mathrm{~PB}-\mathrm{A}$ and 208 PB-C, and 42 for control. The plant height of PB$A$ ranges from $60 \mathrm{~cm}$ to $175 \mathrm{~cm}$, while $\mathrm{PB}-\mathrm{C}$ ranges from $111 \mathrm{~cm}$ to $183 \mathrm{~cm}$. PB-A produced 5 dwarf phenotype plants with a frequency of $2.6 \%$ and 79 semi-dwarf plants with a frequency of $40.3 \%$, while PB-C and the control did not produce dwarf plants (Table 1). Dwarf rice plants caused by ion beam, as observed in the present study was previously reported by Oono et al. (2020). Zheng et al. (2020) showed that heavy-ion beam irradiation was effective in inducing mutations in rice, and revealed the characteristics of mutations at the genome level.

The heading date can be determined by the period of the vegetative growth phase, from seedling to panicle primordium initiation, and reproductive growth phase, from panicle initiation to heading (Vergara and Chang 1985). The vegetative growth phase consists of the basic vegetative phase (BVP), and photoperiod sensitive phase (PSP) (Takahashi 1984). Indonesian local rice varieties grown in mountain areas have a shorter PSP (41 days) and longer BVP (87 days) (Vergara and Chang 1985). The heading date of $\mathrm{PB}-\mathrm{A} \mathrm{M}_{2}$ plants varied between 112 days to 144 days, PB-C varied between 104 days to 149 days, while that of control treatment varied between 121 days to 143 days. The 82 PB-A with a frequency of $41.8 \%$ and 26 PB-C $\mathrm{M}_{2}$ plants with a frequency of $12.5 \%$ was nominated as the putative early heading mutants.

The number of panicles, defined as the number of tillers that produce spikes and seeds, is an important component of grain yield in rice. The number of panicles of PB-A varied between 2 to 33, while PB-C varied between 1 to 23. The highest number of panicles was in PB-A (41 plants) with a frequency of $20.9 \%$, PB-C reached 22 plants with a frequency of $10.58 \%$, and control reached 5 plants with the frequency of $11.9 \%$. This was illustrated by the finding of Sjahril et al. (2020).

There are 101 plants of PB-A, and 47 of PB-C have earlier heading and a larger number of panicles compared to the control (Figure 2 and 3). However, there are only 18 $\mathrm{PB}-\mathrm{A}$ and one $\mathrm{PB}-\mathrm{C}$ have both categorized, i.e. more than 17 panicles and early heading date $(\leq 118$ days $)$. Those lines were selected for $\mathrm{M}_{3}$ generation. This selection uses the concept of normalization to control the variance of the two characters in such a way that both traits have the same relative variance. This selection method was previously reported by Peternelli et al. (2017) in sugarcane, Anshori et al. (2019) in rice, and Fadhli et al. (2020) in corn.

Further studies are required on the selected early heading and high yield putative mutant lines obtained from Toraja local aromatic rice. To correctly assess the early heading date and high yield traits, putative mutant lines and wild type should be crossed. Segregating populations could be derived from crosses between near-isogenic lines which exhibited phenotypic characteristics (Sun et al. 2019). They are much easier to analyze than those derived from remote crosses. Near-isogenic lines have proven to be very useful for genetic studies of quantitative traits such as heading date, which was confirmed by several previous findings (Ding et al. 2011, Fujita et al. 2011, Zhang et al. 2012).

There is an urgent need to study the isolation of mutant genes. The availability of the DNA markers and genome analysis of rice provides a more direct and faster technique for determining genes of interest. Due to this character, it is necessary to find a novel gene related to unique characters. Several genes that cause mutant phenotypes were successfully cloned by map-based cloning from ion beaminduced rice mutants, such as Morita et al. (2019) reported that long grain1 (lin1) mutant contributes to increasing grain weight. Several studies identified early heading date genes (Fujino et al. 2013, Yang et al. 2020), while Ichitani et al. (2014) reported genes related to late heading date in rice. Fujita et al. (2013) argued that the naturally varying SPIKE gene, located in the QTL cluster region of chromosome 4, had a significant impact on yield. However, due to the relatively large rice genome size, the characterization of ion beam-induced mutations at the genomic level was not achieved but has only recently been carried out (Ichida et al. 2019, Li et al. 2019).

\section{Dissimilarity matrix and cluster analysis}

The dissimilarity matrix based on their nine phenotypic traits was used to group the lines and control populations presented in Table 2 . The dissimilarity matrix showed that the highest mean distance was obtained between Control and PB-A.12.2.34, indicating that these are the most divergent lines regarding phenotypic traits evaluated. In contrast, the lowest between PB-A.7.1.9 and PB-A.14.3.1 showed the least divergence and was considered the most similar to the phenotypic traits evaluated.

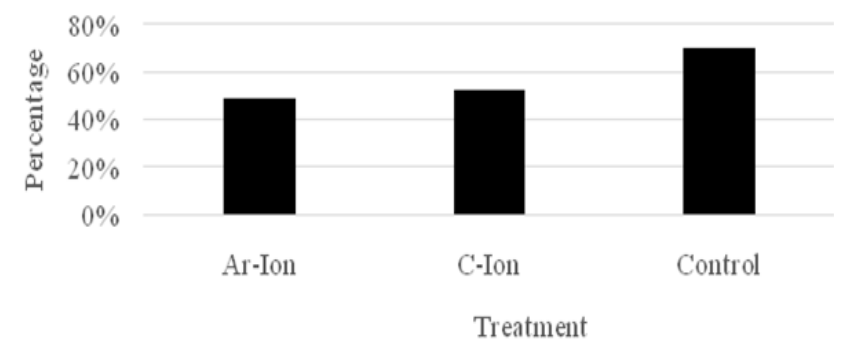

Figure 1. Germination percentage in M1 generation 
Table 1. Growth pattern observed in the $\mathrm{M}_{2}$ generation

\begin{tabular}{|c|c|c|c|c|c|c|c|c|c|c|c|}
\hline \multirow[b]{2}{*}{ Class } & \multirow[b]{2}{*}{ Sub-Class } & \multirow[b]{2}{*}{ Description } & \multicolumn{3}{|c|}{ Control } & \multicolumn{3}{|c|}{ Argon-ion } & \multicolumn{3}{|c|}{ Carbon-ion } \\
\hline & & & Range & $\begin{array}{c}\text { Survival } \\
\text { plant }\end{array}$ & $\begin{array}{c}\text { Frequency } \\
(\%)\end{array}$ & Range & Survival plant & Frequency $(\%)$ & Range & Survival plant & Frequency $(\%)$ \\
\hline \multirow[t]{3}{*}{ Plant Height } & Dwarf & $\leq 100$ & \multirow{3}{*}{$\begin{array}{l}108-166 \\
\mathrm{~cm}\end{array}$} & 0 & 0.0 & \multirow[t]{3}{*}{$60-175 \mathrm{~cm}$} & 5 & 2.6 & \multirow[t]{3}{*}{$111-183 \mathrm{~cm}$} & 0 & 0.00 \\
\hline & Semi-dwarf & $101-141$ & & 13 & 31.0 & & 79 & 40.3 & & 58 & 27.88 \\
\hline & Tall & $\geq 142$ & & 29 & 69.0 & & 112 & 57.1 & & 150 & 72.12 \\
\hline \multirow[t]{3}{*}{ Heading date } & Early & $\leq 118$ & \multirow{3}{*}{$\begin{array}{l}\text { 121-143 } \\
\text { days }\end{array}$} & 0 & 0.0 & \multirow[t]{3}{*}{112 -144 days } & 82 & 41.8 & \multirow[t]{3}{*}{$104-149$ days } & 26 & 12.50 \\
\hline & Medium & $119-132$ & & 37 & 88.1 & & 69 & 35.2 & & 177 & 85.10 \\
\hline & Late & $\geq 133$ & & 5 & 11.9 & & 45 & 23.0 & & 5 & 2.40 \\
\hline \multirow{3}{*}{$\begin{array}{l}\text { Number of } \\
\text { panicles }\end{array}$} & Few & $\leq 8$ & \multirow{3}{*}{$\begin{array}{l}2-24 \\
\text { panicles }\end{array}$} & 19 & 45.2 & \multirow[t]{3}{*}{$2-33$ panicles } & 60 & 30.6 & \multirow[t]{3}{*}{ 1-23 panicles } & 73 & 35.10 \\
\hline & Medium & $9-16$ & & 18 & 42.9 & & 95 & 48.5 & & 113 & 54.33 \\
\hline & Many & $\geq 17$ & & 5 & 11.9 & & 41 & 20.9 & & 22 & 10.58 \\
\hline
\end{tabular}

Table 2. Dissimilarity matrix based on Squared-Euclidean distance in the different lines and control

\begin{tabular}{|c|c|c|c|c|c|c|c|c|c|c|c|c|c|c|c|c|c|c|c|c|}
\hline Lines & $\mathrm{C}$ & G1 & G2 & G3 & G4 & G5 & G6 & G7 & G8 & G9 & G10 & G11 & G12 & G13 & G14 & G15 & G16 & G17 & G18 & G19 \\
\hline $\mathrm{C}$ & & 23.86 & 14.30 & 26.15 & 27.58 & 33.36 & 16.51 & 32.71 & 11.40 & 28.02 & 14.66 & 23.21 & 27.74 & 42.21 & 38.45 & 69.01 & 66.10 & 29.08 & 19.71 & 14.82 \\
\hline G1 & & & 16.03 & 18.83 & 28.60 & 30.85 & 31.33 & 39.04 & 19.71 & 34.40 & 18.09 & 16.62 & 29.14 & 23.45 & 37.18 & 48.21 & 53.08 & 33.31 & 36.51 & 19.78 \\
\hline G2 & & & & 3.44 & 9.47 & 15.84 & 6.46 & 14.48 & 3.17 & 7.62 & 7.19 & 11.72 & 5.93 & 25.70 & 19.28 & 43.04 & 37.74 & 6.95 & 19.75 & 3.33 \\
\hline G3 & & & & & 16.36 & 17.17 & 10.04 & 17.05 & 6.88 & 7.56 & 6.82 & 6.93 & 4.15 & 20.52 & 17.69 & 37.69 & 36.48 & 5.71 & 19.85 & 4.30 \\
\hline G4 & & & & & & 9.00 & 15.21 & 8.60 & 10.82 & 8.27 & 17.58 & 28.08 & 11.69 & 31.00 & 16.51 & 36.86 & 17.93 & 8.99 & 37.24 & 10.33 \\
\hline G5 & & & & & & & 12.73 & 2.38 & 9.67 & 6.53 & 10.67 & 18.40 & 8.74 & 13.12 & 8.33 & 21.79 & 10.08 & 8.11 & 22.35 & 9.38 \\
\hline G6 & & & & & & & & 10.28 & 3.33 & 6.82 & 8.16 & 12.47 & 7.54 & 26.14 & 17.68 & 46.30 & 39.84 & 8.01 & 7.91 & 6.29 \\
\hline G7 & & & & & & & & & 8.53 & 3.75 & 11.88 & 22.95 & 5.86 & 19.83 & 8.75 & 25.74 & 13.90 & 5.75 & 21.99 & 8.99 \\
\hline G8 & & & & & & & & & & 4.88 & 2.66 & 9.77 & 4.71 & 16.77 & 10.95 & 32.26 & 30.71 & 6.24 & 10.15 & 1.62 \\
\hline G9 & & & & & & & & & & & 7.43 & 15.90 & 1.40 & 19.52 & 6.75 & 26.62 & 18.47 & 0.74 & 18.91 & 3.60 \\
\hline G10 & & & & & & & & & & & & 4.53 & 5.72 & 11.34 & 11.29 & 29.00 & 30.60 & 7.73 & 8.77 & 1.61 \\
\hline G11 & & & & & & & & & & & & & 12.20 & 14.47 & 21.66 & 41.02 & 43.87 & 14.50 & 9.99 & 7.65 \\
\hline G12 & & & & & & & & & & & & & & 17.94 & 9.71 & 28.19 & 23.67 & 1.14 & 17.58 & 2.90 \\
\hline G13 & & & & & & & & & & & & & & & 9.10 & 9.81 & 22.16 & 22.12 & 22.23 & 16.66 \\
\hline G14 & & & & & & & & & & & & & & & & 8.46 & 11.68 & 10.50 & 23.72 & 10.92 \\
\hline G15 & & & & & & & & & & & & & & & & & 13.57 & 31.60 & 49.21 & 31.41 \\
\hline G16 & & & & & & & & & & & & & & & & & & 20.86 & 55.45 & 27.00 \\
\hline G17 & & & & & & & & & & & & & & & & & & & 20.98 & 3.35 \\
\hline G18 & & & & & & & & & & & & & & & & & & & & 13.65 \\
\hline G19 & & & & & & & & & & & & & & & & & & & & \\
\hline
\end{tabular}

Note: C: Control, G1: PB-A.5.1.13, G2: PB-A.5.3.36, G3: PB-A.5.3.45, G4: PB-A.6.1.9, G5: PB-A.6.1.12 G6: PB.A.6.1.13, G7: PB-A.6.1.15, G8: PB-A.8.1.5, G9: PB-A.7.1.9, G10: PBA.7.1.30, G11: PB-A.7.1.41, G12: PB-A.12.2.4, G13: PB-A.12.2.11, G14: PB-A.12.2.12, G15: PB-A.12.2.34, G16: PB-A.14.2.14, G17: PB-A.14.3.1, G18: PB-A.14.4.3, G19: PB-C.20.1.49 


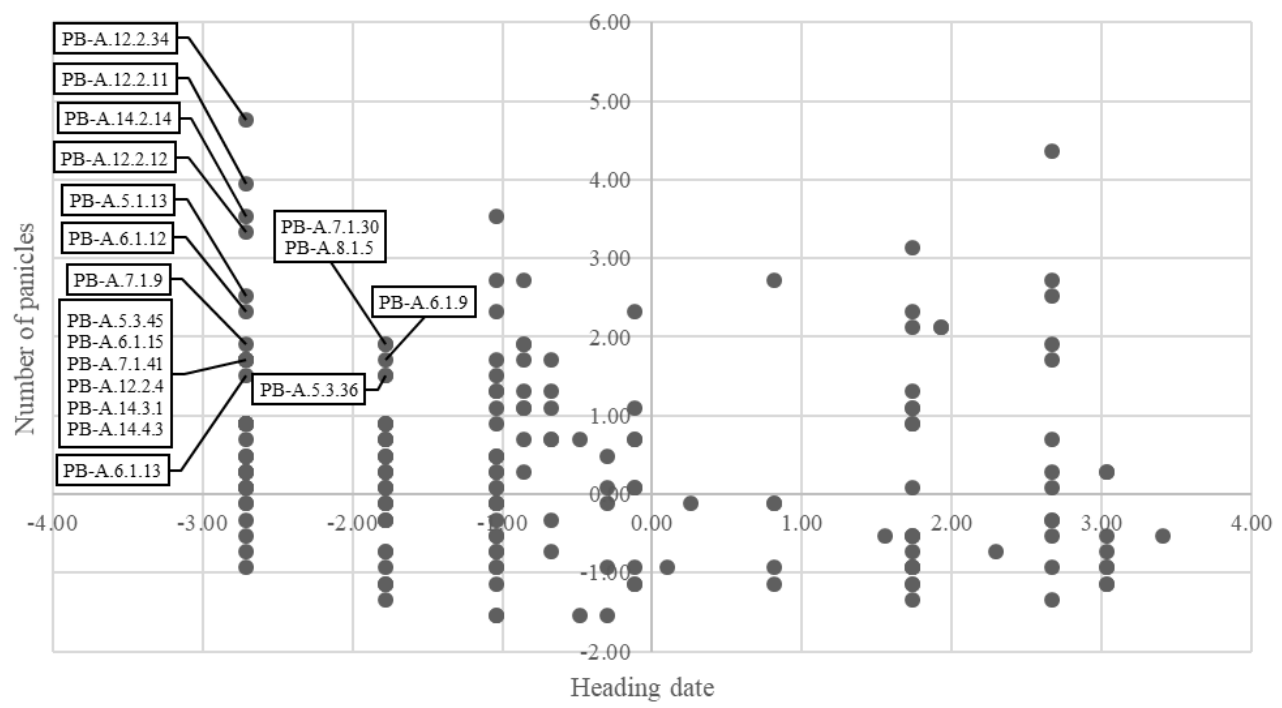

Figure 2. Mapping the selection of heading date and the number of panicles in $\mathrm{M}_{2}$ plants irradiated with Argon-ion in local Toraja aromatic rice "Pare Bau", Indonesia. Eighteen $\mathrm{M}_{3}$ lines were nominated

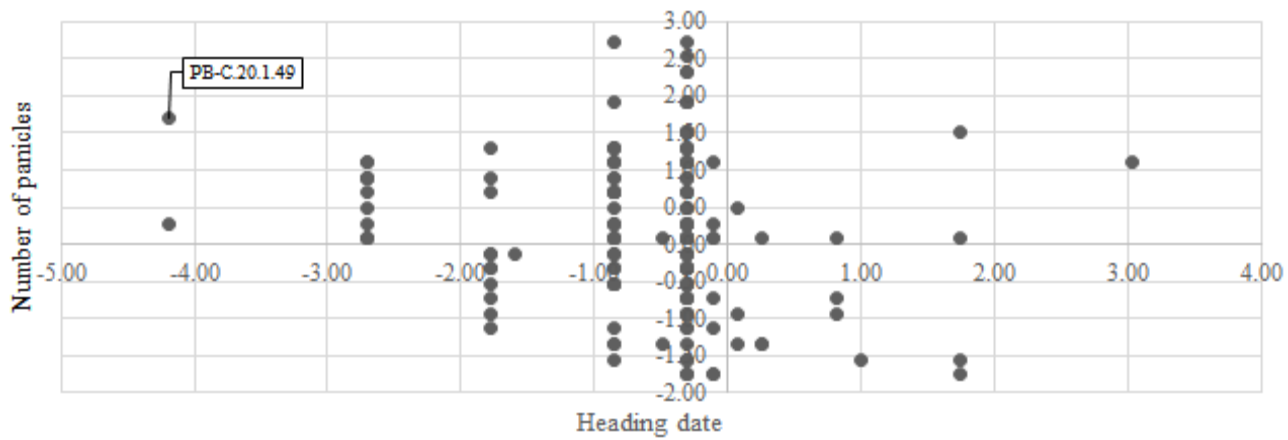

Figure 3. Mapping the selection of days to heading and the number of panicles in $\mathrm{M}_{2}$ plants irradiated with Carbon-ion in local Toraja aromatic rice "Pare Bau", Indonesia. One $\mathrm{M}_{3}$ line was nominated

Cluster analysis of 19 selected lines and control based on nine quantitative phenotypic traits showed seven clusters at level 5 (Figure 4). The maximum number of lines was included in cluster III and VII (6 lines), followed by cluster VI (3 lines), cluster IV (2 lines), cluster I, II, and V (1 line). Several studies have previously used this method (Oladosu et al. 2014, Liang et al. 2015, Tahjib-UlArif et al. 2018). The dendrogram shows that varieties in one cluster are primarily identical, have less diversity, and most similar objects are linked by gradually diminished similarity criteria (Sava and Popa, 2011). The aromatic rice lines show significant genetic variations in morphological traits as observed in this study. It was important to note that in the control and two lines formed an independent cluster, which showed that considerable genetic variation has performed quantitative phenotypic traits in some mutant lines compared to control due to mutagenic treatments.

The effectiveness of quantitative phenotypic traits in grouping rice lines has been demonstrated. It has been shown that morphologically based genetic divergence analysis among rice lines can be used to identify and distinguish different lines in a population (Franco et al. 2001). The phenotypic characterization of mutant populations in their parents is an essential part of the mutation breeding program, and the efficient population of various interrelated traits, especially quantitative traits, is the key to successful selection in the subsequent generations. For the future breeding program, lines are selected from diverged clusters with better phenotypic performance, or each cluster, one parent was selected and then the selected lines are subjected to crossing.

\section{Correlation coefficient analysis}

Correlation coefficient analysis was carried out to determine how selecting one character will cause a simultaneous change in other characters and determine the relationship between character and fitness. Breeders used correlation coefficient analysis to show a positive relationship between yield and other traits that enhance yield in cereals, such as rice (Ogunbayo et al. 2014), 
sorghum (Mutava et al. 2011), wheat (Lopes et al. 2012), and corn (Zabed et al. 2016).

All calculated correlation coefficients are listed in Table 3. The number of tillers showed positive correlation with plant height (0.59). The number of panicles exhibited significantly positive correlation with plant height $(0.54)$ and the number of tillers (0.94). Grain weight per panicle was found to be positively correlated with plant height (0.49). The number of fertile grains had positive association with plant height $(0.45)$ and grain weight per panicle (0.98). The trait of 100-grain weight was found to be positively correlated with the heading date (0.62). Significant positive correlations with plant yield were recorded for the traits of plant height $(0.71)$, the number of tillers (0.81), the number of panicles $(0.87)$, and grain weight per panicle (0.46). Close relationships between traits can play a positive or negative role in the transmission of traits through genetic introgression since strong selection for the desired trait can support the presence of other traits.

In this study, plant height was closely related to yield. Dwarf mutant lines may be restricted in the rice breeding program due to negative effects on reduction in the number of panicles, grain weight per panicle, number of fertile grains, and plant yield. According to Peng et al. (1994), short plant height causes leaf crowding, poor ventilation, and reduced crowding conditions, which result in the decreased photosynthetic efficiency. The mutant plants with the dwarf phenotype were not suitable for direct commercial cultivation. They can be used in hybridization to pass some of their beneficial traits to other high-yielding rice varieties. The number of panicles was correlated with the number of tillers, and the number of tillers that are too high or low will affect the yield of rice. This finding is consistent with previous research that showed a positive association between the number of panicles and rice yield (Ranawake and Amarasinghe 2014). The grain weight per panicle also correlated with plant yield, and the results conformed to Akinwale et al. (2011). Therefore, it can be suggested that lines should possess more plant height, number of tillers, number of panicles, and grain weight per panicle for increasing rice yield. These traits are important yield contributing traits, and selection based on these traits would be most effective.

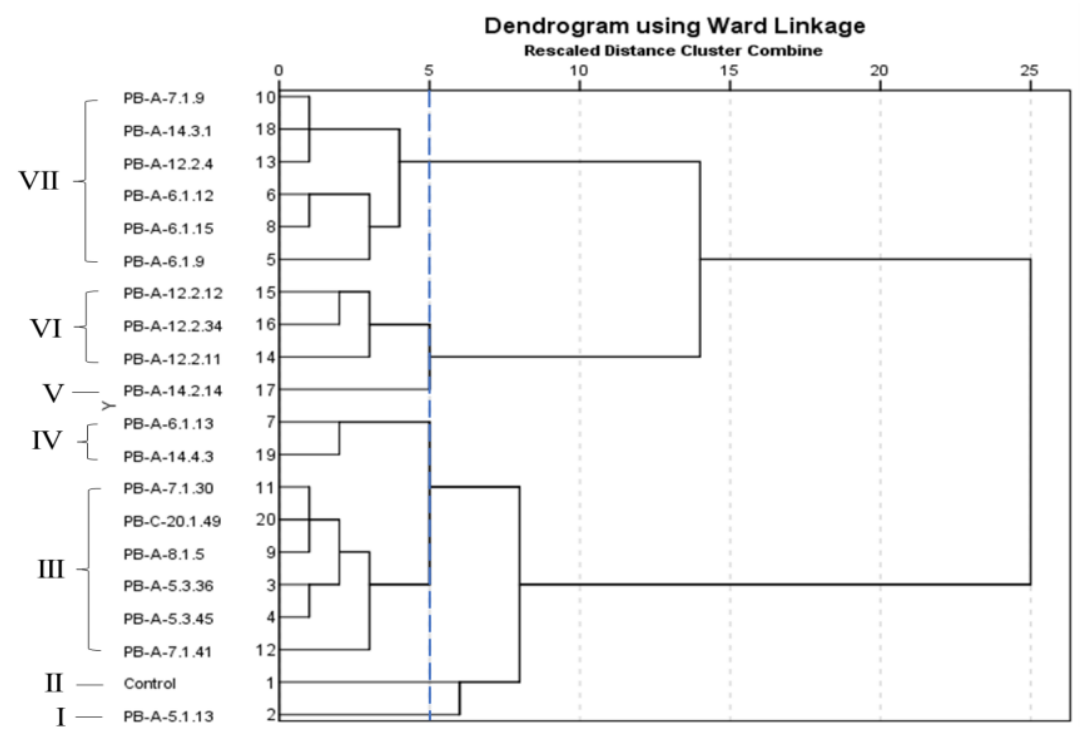

Figure 4. Dendrogram of 19 selected lines and one control based on nine quantitative traits

Table 3. The phenotypic correlation coefficient of different traits obtained from 19 rice lines

\begin{tabular}{|c|c|c|c|c|c|c|c|c|c|}
\hline Traits & $\begin{array}{c}\text { Plant } \\
\text { height }\end{array}$ & $\begin{array}{c}\text { Heading } \\
\text { date }\end{array}$ & $\begin{array}{l}\text { No. of } \\
\text { tillers }\end{array}$ & $\begin{array}{c}\text { No. of } \\
\text { panicles }\end{array}$ & $\begin{array}{c}\text { Grain } \\
\text { weight per } \\
\text { panicle }\end{array}$ & $\begin{array}{l}\text { No. of } \\
\text { fertile } \\
\text { grains }\end{array}$ & $\begin{array}{l}\text { No. of } \\
\text { sterile } \\
\text { grains }\end{array}$ & $\begin{array}{c}100- \\
\text { grain } \\
\text { weight }\end{array}$ & $\begin{array}{l}\text { Plant } \\
\text { yield }\end{array}$ \\
\hline Plant height & 1.00 & $-0.38^{\mathrm{ns}}$ & $0.59^{* * *}$ & $0.54^{*}$ & $0.49^{*}$ & $0.45^{*}$ & $-0.13^{\mathrm{ns}}$ & $0.16^{\mathrm{ns}}$ & $0.71^{* *}$ \\
\hline Heading date & & 1.00 & $-0.30^{\text {ns }}$ & $-0.33^{\text {ns }}$ & $-0.30^{\mathrm{ns}}$ & $-0.28^{\text {ns }}$ & $0.02^{\mathrm{ns}}$ & $0.62^{* *}$ & $-0.32^{\mathrm{ns}}$ \\
\hline Number of tillers & & & 1.00 & $0.94^{* *}$ & $0.20^{\mathrm{ns}}$ & $0.12^{\mathrm{ns}}$ & $0.14^{\mathrm{ns}}$ & $0.22^{\mathrm{ns}}$ & $0.81^{* *}$ \\
\hline Number of panicles & & & & 1.00 & $0.13^{\text {ns }}$ & $0.07^{\mathrm{ns}}$ & $0.19^{\text {ns }}$ & $0.26^{\mathrm{ns}}$ & $0.87^{* *}$ \\
\hline Grain weight per panicle & & & & & 1.00 & $0.98^{* *}$ & $-0.21^{\mathrm{ns}}$ & $0.17^{\mathrm{ns}}$ & $0.46^{*}$ \\
\hline Number of fertile grains & & & & & & 1.00 & $-0.21^{\mathrm{ns}}$ & $0.09^{\text {ns }}$ & $0.38^{\text {ns }}$ \\
\hline Number of sterile grains & & & & & & & 1.00 & $-0.33^{\text {ns }}$ & $0.01^{\mathrm{ns}}$ \\
\hline 100-grain weight & & & & & & & & 1.00 & $0.32^{\text {ns }}$ \\
\hline Plant yield & & & & & & & & & 1.00 \\
\hline
\end{tabular}

Note: ns: indicates non-significance; $*$ : indicates significance at $\mathrm{p} \leq 0.05 ; * *$ : indicates significance at $\mathrm{p} \leq 0.01$ 
The evaluation of these mutants in subsequent breeding cycles can be useful in the development of selection indices for important traits in rice. Nineteen selected lines (18 PB$\mathrm{A}$ and 1 PB-C) for early heading and high yield compared to control, were suitable for aromatic rice breeding programs from this population. Consequently, it is expected that there will be significant advancements in the use of ion beam breeding. We recommended that future studies should explore molecular markers to validate the findings of this study.

\section{ACKNOWLEDGEMENTS}

The authors express the deepest gratitude to the Directorate General of Resources for Science, Technology and Higher Education (DG-RSTHE), Ministry of Education and Culture, Indonesia for funding this research through the master's degree to the doctoral scholarship program for excellence undergraduate. We thank to Trisnawaty AR, Muh. Mukhtadir Putra, and all colleagues for the help during the study.

\section{REFERENCES}

Abe T, Ryuto H, Fukunishi N. 2012. Ion beam radiation mutagenesis. In Shu QY, Forster BP, Nakagawa H (eds). Plant Mutation Breeding and Biotechnology. CABI, UK

Akinwale MG, Gregorio G, Nwilene F, Akinyele BO, Ogunbayo SA, Odiyi AC. 2011. Heritability and correlation coefficient analysis for yield and its components in rice (Oryza sativa L.). Afr Journal Plant Sci 5 (3): 207-212.

Anshori MF, Purwoko BS, Dewi IS, Ardie SW, Suwarno WB. 2019. Selection index based on multivariate analysis for selecting doubledhaploid rice lines in lowland saline prone area. SABRAO J Breed Genet 51 (2): 161-174.

Augustina UA, Iwunor OP, Ijeoma OR. 2013. Heritability and character correlation among some rice genotypes for yield and yield components. J Plant Breed Genet 1 (2): 73-84.

Chen YL, Liang HL, Ma XL, Lou SL, Xie YY, Liu ZL, Chen LT, Liu YG. 2013. An Efficient Rice Mutagenesis System Based on Suspension-Cultured Cells. J Integr Plant Biol 55 (2): 122-130. DOI: 10.1111/jipb. 12000

Ding X, Li X, Xiong L. 2011. Evaluation of near-isogenic lines for drought resistance QTL and fine mapping of a locus affecting flag leaf width, spikelet number, and root volume in rice. Theor Appl Genet 123 (5): 815-826. DOI: 10.1007/s00122-011-1629-1.

Fadhli N, Farid M, Rafiuddin, Efendi R, Azrai M, Anshori MF. 2020 Multivariate analysis to determine secondary characters in selecting adaptive hybrid corn lines under drought stress. Biodiversitas 21 (8): 3617-3624. DOI: 10.13057/biodiv/d210826.

Fekih R, Takagi H, Tamiru M, Abe A, Natsume S, Yaegashi H, Sharma S, Sharma S, Kanzaki H, Matsumura H, Saitoh H, Mitsuoka C, Utsushi H, Uemura A, Kanzaki E, Kosugi S, Yoshida K, Cano L, Kamoun S, Terauchi R. 2013. MutMap+: genetic mapping and mutant identification without crossing in rice. PloS One 8: e68529. DOI: 10.1371/journal.pone.0068529.

Franco J, Crossa J, Ribaut JM, Bertran J, Warburton ML and Khairallah M. 2001. A method for combining molecular markers and phenotypic attributes for classifying plant genotypes. Theor Appl Genet 103: 944 952. DOI: $10.1007 / \mathrm{s} 001220100641$.

Fujino K, Yamanouchi U, Yano M. 2013. Roles of the Hd5 gene controlling heading date for adaptation to the northern limits of rice cultivation. Theor Appl Genet 126 (3): 611-618. DOI: $10.1007 / \mathrm{s} 00122-012-2005-5$.
Fujita D, Santos RE, Ebron LA, Fukuta Y, Kobayashi N. 2011. Characterization of quantitative trait locus for days to heading in near-isogenic lines with the genetic background of Indica-type rice variety IR64 (Oryza sativa). Plant breed 130 (5): 526-532. DOI: 10.1111/j.1439-0523.2011.01864.x.

Fujita D, Trijatmiko KR, Tagle AG, Sapasap MV, Koide Y, Sasaki K, Tsakirpaloglou N, Gannaban RB, Nishimura T, Yanagihara S, Fukuta Y. 2013. NAL1 allele from a rice landrace greatly increases yield in modern indica cultivars. Proc Natl Acad Sci USA 110 (51): 20431 20436. DOI: $10.1073 /$ pnas.1310790110.

Hayashi M, Crofts N, Oitome NF, Fujita N. 2018. Analyses of starch biosynthetic protein complexes and starch properties from developing mutant rice seeds with minimal starch synthase activities. BMC Plant Biol 18 (1): 1-15. DOI: 10.1186/s12870-018-1270-0.

$\mathrm{Hu}$ Y, Li S, Xing Y. 2019. Lessons from natural variations: artificially induced heading date variations for improvement of regional adaptation in rice. Theor Appl Genet 132: 383-394. DOI: 10.1007/s00122-018-3225-0.

Huang R, Jiang L, Zheng J, Wang T, Wang H, Huang Y, Hong Z. 2013. Genetic bases of rice grain shape: so many genes, so little known. $\begin{array}{lllll}\text { Trends Plant } & \text { Sci. } 18 & \text { (4): } & \text { 218-226. }\end{array}$ 10.1016/j.tplants.2012.11.001

Ichida H, Morita R, Shirakawa Y, Hayashi Y, Abe T. 2019. Targeted exome sequencing of unselected heavy-ion beam-irradiated populations reveals less-biase mutation characteristics in the rice genome. Plant J 98 (2): 301-314. DOI: 10.1111/tpj.14213.

Ichitani K, Yamaguchi D, Taura S, Fukutoku Y, Onoue M, Shimizu K, Hashimoto F, Sakata Y, Sato M. 2014. Genetic analysis of ion-beam induced extremely late heading mutants in rice. Breed Sci 64 (3): 222230. DOI: 10.1270 /jsbbs.64.222.

Ishikawa S, Ishimaru Y, Iguraa M, Kuramata M, Abe T, Senoura T, Hase Y, Arao T, Nishizawa NK, Nakanishi H. 2012. Ion-beam irradiation, gene identification, and marker-assisted breeding in the development of low-cadmium rice. Proc Natl Acad Sci USA 109 (47): 1916619171. DOI: 10.1073/pnas.1211132109.

Jain SM. 2005. Major mutation-assisted plant breeding programs supported by FAO/IAEA. Plant Cell Tiss Org Cult 82 (1): 113-123. DOI: $10.1007 / \mathrm{s} 11240-004-7095-6$.

Jung C, Muller AE. 2009. Flowering time control and applications in plant breeding. Trends Plant Sci 14 (10): 563-573. DOI: 10.1016/j.tplants.2009.07.005.

Kazama Y, Hirano T, Saito H, Liu Y, Ohbu S, Hayashi Y, Abe T. 2011. Characterization of highly efficient heavy-ion mutagenesis in Arabidopsis thaliana. BMC Plant Biol 11 (1): 1-10. DOI: 10.1186/1471-2229-11-161

Ke C, Guan W, Bu S, Li X, Deng Y, Wei Z, Wu W, Zheng Y. 2019. Determination of absorption dose in chemical mutagenesis in plants. PloS One 14: e0210596. DOI: 10.1371/journal.pone.0210596.

Kobayashi Y, Weigel D. 2007. Move on up, it's time for change-mobile signals controlling photoperiod-dependent flowering. Genes Dev 21 (19) : 2371 2384. DOI: 10.1101/gad.1589007.

Khush GS. 2013. Strategies for increasing the yield potential of cereals: case of rice as an example. Plant Breed 132 (5):433-436. DOI: 10.1111/pbr.1991

Kumar AP, Boualem A, Bhattacharya A, Parikh S, Desai N, Zambelli A, Leon A, Chatterjee M, Bendahmane A. 2013. SMART-sunflower mutant population and reverse genetic tool for crop improvement. BMC Plant Biol 13 (1): 1-8. DOI: 10.1186/1471-2229-13-38.

Li R, Li M, Ashraf U, Liu S, Zhang J. 2019. Exploring the relationships between yield and yield-related traits for rice varieties released in China from 1978 to 2017. Front Plant Sci 10: 1-12. DOI: 10.3389/fpls.2019.00543.

Liang S, Ren G, Liu J, Zhao X, Zhou M, McNeil D, Ye G. 2015. Genotype-by-environment interaction is important for grain yield in irrigated lowland rice. Field Crops Res 180: 90-99. DOI: 10.1016/j.fcr.2015.05.014.

Lopes MS, Reynolds MP, Jalal-Kamali MR, Moussa M, Feltaous Y, Tahir IS, Barma N, Vargas M, Mannes Y, Baum M. 2012. The yield correlations of selectable physiological traits in a population of advanced spring wheat lines grown in warm and drought environments. Field Crops Res 128: 129-136. DOI: 10.1016/j.fcr.2011.12.017. 
Luz VKD, Oliveira VD, Maltzahn LE, Venske E. 2020. Mutation breeding for rice grain quality: aspects, considerations, and promising results. In: Oliveira ACD, Pegoraro C, Viana VE (eds). The future of rice Demand: Quality beyond productivity. Springer, Switzerland.

Maulana Z, Kuswinanti T, Sennang NR, Syaiful SA. 2014. Genetic diversity of locally rice germplasm from Tana Toraja and Enrekang Based on RAPD (Random Amplified Polymorphism DNA) Markers. Int J Sci Technol Res 3 (4): 198-202. [Indonesian]

Morita R, Ichida H, Ishii K, Hayashi Y, Abe H, Shirakawa Y, Ichinose K, Tsuneizumi K, Kazama T, Toriyama K, Sato T, Abe T. 2019. LONG GRAIN 1: a novel gene that regulates grain length in rice. Mol Breed 39 (9): 135-142. DOI: 10.1007/s11032-019-1032-1.

Mostafa HH, Wang H, Shen D, Qiu Y, Li X. 2015. Sprout differentiation and mutation induction of garlic (Allium sativum L.) callus exposed to gamma radiation. Plant Growth Regul 75 (2): 465-471. DOI 10.1007/s10725-014-0009-7.

Mutava RN, Prasad PV, Tuinstra MR, Kofoid KD, Yu J. 2011. Characterization of sorghum genotypes for traits related to drought tolerance. Field Crops Res 123 (1): 10-18. DOI: 10.1016/j.fcr.2011.04.006.

Ogunbayo SA, Ojo DK, Sanni KA, Akinwale MG, Toulou B, Shittu A, Idehen EO, Popoola AR, Daniel IO, Gregorio GB. 2014. Genetic variation and heritability of yield and related traits in promising rice genotypes (Oryza sativa L.). J Plant Breed Crop Sci 6 (11): 153-159. DOI: $10.5897 /$ JPBCS2014.0457.

Oladosu Y, Rafii MY, Abdullah N, Abdul Malek M, Rahim HA, Hussin G, Abdul Latif M, Kareem I. 2014. Genetic variability and selection criteria in rice mutant lines as revealed by quantitative traits. Scientific World J 2014: 190531. DOI: 10.1155/2014/190531.

Oono Y, Ichida H, Morita R, Nozawa S, Satoh K, Shimizu A, Abe T, Kato H, Hase Y. 2020. Genome sequencing of ion-beam-induced mutants facilitates detection of candidate genes responsible for phenotypes of mutants in rice. Mutation Research/Fundamental and Molecular Mechanisms of Mutagenesis 821: 111691. DOI: 10.1016/j.mrfmmm.2020.111691

Peng S, Khush GS, Cassman KG. 1994. Evolution of the new plant ideotype for increased yield potential. In: Cassman KG (ed) Breaking the yield barrier. IRRI, Los Banos.

Peternelli LA, Moreira EFA, Nascimento M, Cruz CD. 2017. Artificial neural networks and linear discriminant analysis in early selection among sugarcane families. Crop Breed. Appl Biotechnol 17 (4): 299 305. DOI: 10.1590/1984-70332017v17n4a46.

Ranawake AL, Amarasinghe UGS. 2014. Relationship of Yield and Yield Related Traits of Some Traditional Rice Cultivars in Sri Lanka as Described by Correlation Analysis. J Sci Res 3 (18): 2395-2403. DOI: 10.9734/JSRR/2014/12050.

Roychowdhury R, Tah J. 2013. Mutagenesis-a potential approach for crop improvement. In Hakeem KR, Ahmad P, Ozturk M (eds) Crop Improvement: New Approaches and Modern Techniques. Springer Science+Business Media, New York

Sava FA, Popa RI. 2011. Personality types based on the big five model. A cluster analysis over the Romanian population. Cognition Brain Behav Interdiscipl J 15 (3): 359-384.
Sjahril R, Trisnawaty, Riadi M, Rafiuddin, Sato T, Toriyama K, Hayashi Y, Abe T. 2020. Selection of early maturing and high yielding mutants of toraja local red rice grown from M2-M3 population after ion beam irradiation. Hayati J Biosci 27 (2): 166-173. DOI: 10.4308/hjb.27.2.166.

Sun Z, Du J, Pu X, Ali MK, Yang X, Duan C, Ren M, Li X, Zeng Y. 2019. Near-isogenic lines of japonica rice revealed new qtls for cold tolerance at booting stage. Agronomy 9 (1): 40 . DOI: 10.3390/agronomy9010040.

Tahjib-Ul-Arif M, Sayed MA, Islam MM, Siddiqui MN, Begum SN, Hossain MA. 2018. Screening of rice landraces (Oryza sativa L.) for seedling stage salinity tolerance using morpho-physiological and molecular markers. Acta Physiologiae Plantarum 40 (4): 1-12. DOI: 10.1007/s11738-018-2645-4.

Talebi AB, Talebi AB, Shahrokhifar B. 2012. Ethyl methane sulphonate (EMS) induced mutagenesis in Malaysian rice (cv. MR219) for lethal dose determination. Amer J Plant Sci 3 (12): 1-5. DOI: 10.4236/ajps.2012.312202

Takahashi N. 1984. Differentiation of ecotypes in cultivated rice. In Tsunoda S, Takahashi N (eds). Biology of Rice. Japan Scientific Societies Press, Tokyo.

Vergara BS, Chang TT. 1985. The flowering response of the rice plant to photoperiod: A review of the literature. 4th ed. International Rice Research Institute, Philippines.

Ward JH. 1963. Hierarchical grouping to optimize an objective function. J American Stat Assoc 58 (301): 236-244. DOI: 10.1080/01621459.1963.10500845.

Yang D, Cheng C, Zheng X, Ye X, Ye N, Huang F. 2020. Identification and fine mapping of a major QTL, qHD19, that plays pleiotropic roles in regulating the heading date in rice. Mol Breed 40 (3): 30-41. DOI: 10.1007/s11032-020-1109-X.

Ye J, Niu X, Yang Y, Wang S, Xu Q, Yuan X, Yu H, Wang Y, Wang S, Feng Y, Wei X. 2018. Divergent Hd1, Ghd7, and DTH7 alleles control heading date and yield potential of japonica rice in Northeast China. Front Plant Sci 9: 35. DOI: 10.3389/fpls.2018.00035.

Zabed H, Boyce AN, Faruq G, Sahu JN. 2016. A comparative evaluation of agronomic performance and kernel composition of normal and high sugary corn genotypes (Zea mays L.) grown for dry-grind ethanol production. Inds Crops Prod 94: 9-19. DOI: 10.1016/j.indcrop.2016.08.026.

Zhang Y, Yu C, Lin J, Liu J, Liu B, Wang J, Huang A, Li H, Zhao T. 2017. OsMPH1 regulates plant height and improves grain yield in rice. PLoS One (12): e0180825. DOI: 10.1371/journal.pone.0180825

Zhang ZH, Wang K, Guo L, Zhu YJ, Fan YY, Cheng SH, Zhuang JY. 2012. Pleiotropism of the photoperiod-insensitive allele of Hd1 on heading date, plant height and yield traits in rice. PloS one 7 (12): e52538. DOI: 10.1371/journal.pone.0052538.

Zheng Y, Li S, Huang J, FU H, Zhou L, Furusawa Y, Shu Q (2020). Mutagenic effect of three ion beams on rice and identification of heritable mutations by whole-genome sequencing. Plants 9 (5): 551567. DOI: 10.3390/plants9050551 